\title{
Move on, Move on! \\ What it is to be Chinese in Australia today
}

\author{
Chek Ling
}

\begin{abstract}
The Chinese are all right now. On the whole the mainstream population is quite relaxed about the Chinese presence in their midst. That of course was not the case for the 100 years to the end of WWII. And so it should come as no surprise that now and again old scars will resurface. Yet the Chinese have metamorphosed in the psyche of mainstream Australia: honorary whites like Li Cunxin, lionized professionals like Victor Chang, are neon-lit signs of this change. All the same, as a huayi (overseas Chinese) immigrant, my observations over the last 50 years have compelled me to conclude that there is one last gate for the present-day Chinese to walk through, and that it is time for the remaining rearguards of White Australia to consciously remove themselves from that gate.
\end{abstract}

Lambing Flat has lain in my subconscious, ever since I first heard of it some forty years prior. At the time, I would have been hard at it, trying to make a life in Australia, as an engineer, a situation I did not enjoy, having studied engineering by accident and not finding it to my liking after the first week. I had flown into Melbourne, on a Colombo Plan scholarship, a week or two before the lectures started in 1962, from Sarawak, the soon to be abandoned British Colony. Sarawak had been the private fiefdom of three generations of the Brooke family of Great Britain, until the end of the Second World War.

My wife, a fifth generation Victorian of Anglo-Scottish heritage, was probably the one who told me about Lambing Flat, early in our marriage. But at the time I had neither the intellectual grounding nor the inclination to delve into it. All the same, Geoffrey Blainey's campaign against Asian immigration in 1984 was to indelibly etch in my psyche the recurrent question of what it is to be a Chinese in contemporary Australia.

Lambing Flat is hundreds and hundreds of miles away from Melbourne or Brisbane, the two cities where I have lived to make a living. It is however just two hours by car from Canberra where two of our children then worked in 2008. 
The heat of summer was behind us, at last. We have both retired. So it was time to spend a day in the town of Young, to see Lambing Flat in the flesh, after all these years, during our visit to Canberra.

We got to the Information Centre in Young and got the 'fact sheets' for Lambing Flat. Twenty minutes later, on the side of the now gravelly road, we noticed a sign almost camouflaged under the gum trees.

'Welcome to the Lambing Flat Chinese Tribute Gardens', with the two Chinese characters, 欢迎.

A little submarine emerged from the depth of my soul.

Lambing Flat was the scene of the best-known, and most persistently-planned persecution of the Chinese gold seekers in $19^{\text {th }}$ century Australia. Yet not a word of that history was to be found in or near the ‘Tribute Gardens’.

What happened? ... I wondered, quietly.

A plaque tells us about the history of Chinaman's Dam that is now part of the beautiful lake in the Tribute Gardens. Not a word more.

The fact sheets at the Information centre give us the history of how the gardens came about in the 1990s and how they became dedicated: 'In recognition of the contribution of the Chinese community to the settlement of Young in the 1860s and to the ongoing contributions of the Chinese people (community) to Australia as a Nation.'

The word, community, appears in a second fact sheet, in place of the word, people. ... hmm... perhaps a hint of disorientation about a community, a race, and even a nation? 
I can't help feeling that the dark side of Lambing Flat has been whited out, in the rush to refashion the memory of the early Chinese in the souls of white Australia. It must have been still too raw for many white Australians to acknowledge that dark shadow of our nation's birth, as there had been no wake for the midnight burial of White Australia, no memorial service for its passing. ... No doubt it is much easier for the uncleansed soul to just 'move on' instead.

The gardens are beautiful, oasised in the wilderness that has now reclaimed the desecrated terrain left behind by the early miners and pastoralists: serene, generous in space, and just a little quaint in one respect - a small Chinese pavilion with its loud colours on the top of a rise, reached by a meandering path leading from a stone bridge across a narrow part of the lake.

So here in the outskirts of a country town, the Chinese are honoured for their ongoing contributions to Australia as a Nation. ... Why not in Sydney, or Melbourne where the latter-day Chinese mostly reside? Or is this all for the international tourists? Unlikely... who's gonna come here from overseas? More likely, just a warm story about how we have triumphed over our (unacknowledged) racist birth? ... I could not help thinking to myself.

The Chinese are also honoured for their contribution to the settlement of Young in the 1860s. This really stirs me up. Whilst this is no doubt true of the intention of the project initiators, however naïve, it is nowhere near the whole truth about the Chinese settlement in Young. At the request of the city elders, some of the Chinese, driven out in the 'Lambing Flat Riot', did come back to Young to restart their businesses and services, after the gold had petered out and Young was fast becoming a ghost town as the white fortune seekers disappeared overnight.

... So they think they have done the right thing by these early Chinese. But do they not see that in so doing they have subliminally laid the grounds for thinking about the Chinese as a useable people - when they are needed, that is! After all, they were treated badly in those early days, sometimes violently when the stakes were high, if they happened to be an obstacle to the White man's intentions or a thorn on the side of his God-given rights. 
I enjoyed the gardens. On the way back to the town, the taxi driver pointed out a sign on the roadside where the Riot Act was read out to the white mob on 14 July 1861. We stopped at the Museum. Two volunteer ladies, well past their three scores and ten, greeted us warmly. The Roll Up banner that headed that violent eviction of the 2000 Chinese miners on 30 June 1861 was prominently displayed near the entrance. Many more artifacts from that inglorious episode were on show, curated better than small town museums I had seen elsewhere in NSW and Queensland.

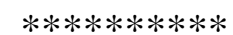

Some 18 months earlier I had attended a Federal Government funded four day workshop on Chinese Australian Cultural Heritage. The workshop was intended to rejuvenate a project that had lain in the doldrums for some years. It turned out to be largely a show and tell, with no expressed direction or vision. Just do it. Anything with a Chinese connection would do - a headstone somewhere, a collection of porcelain taken from a vanished Joss House - the list went on. And there was half a day in a computer lab to showcase computer software that one could upload one’s heritage projects onto.

On the first day of the workshop one government officer rolled out a substantial project they had undertaken, in connection with the Lambing Flat 'Riot' and mentioned in a throwaway manner something about opium smoking. My ears burned. ... How could a public servant be so sloppy historically, and so immature culturally when we are supposed to have moved on from the stereotypical images of john chinaman, infused into the mindscape of white Australia until the 1970s?... And before I could manage to refine my thoughts I had blurted out, rather bluntly, that if opium was to be mentioned then something ought to be said about how the Chinese got addicted to opium, en masse. The white career-multiculturalist was a little rattled, but (the late) Henry Chan, sitting in the Chair, piped up: 'You are a bit out of date, ...! I've recently read two books on opium-smoking in China. In fact it is a custom, amongst Chinese gentlemen, that they retire after dinner and have a pipe or two, long before the Opium War.' I was aghast and irritated: 'I don't really want to debate this issue, Henry, but what you've said does not in any way detract from what I have raised.' Henry Chan had become the god-father of the Chinese Australian Cultural Heritage project. He had put a lot of effort into it and had presided over a 
number of Chinese heritage projects in NSW. He was born in China, grew up in New Zealand, and spent most of his adult life in Australia. He had spent the last 12 years of his working life as a lecturer in Chinese history in a regional university in New South Wales, before he retired and took up Chinese cultural heritage with much enthusiasm.

Why did he do that? Was he trying to put me down, for spoiling his show? Did he think that it was impolite of me to bite the hand that feeds us? ... the bleeding born-again john chinaman! I ruminated.

$* * * * * * *$

The Rotary Club of Young started work on Chinaman’s Dam in 1992 to beautify this public reserve that had been set aside for family picnics and swimming many years previously. A new entrance to the reserve, donated by Taronga Zoo and which formed the gateway to the Zoo's Panda exhibition some years earlier, was erected - the beginnings of a Chinese Garden.

By the end of the year the Chinese Embassy in Canberra had donated the proceeds from the sale of Chinese ceramic and craft items it had provided to an exhibition at the Burrangong Gallery in Young.

On Australia Day the following year, 1993, the Federal government gave $\$ 75000$ for the project, in response to a deputation led by the prime mover of the project, Rotarian Leo Callinan.

Then in November 1996 the Rotarians handed the project over to the Young Shire Council. No doubt it had gotten too big, financially. Its Mayor soon prevailed upon the Council to dedicate the Garden thus: 'in recognition of the contribution of the Chinese community to the settlement of Young in the 1860's (sic) and the ongoing contribution of the Chinese community to Australia as a Nation.’

... Oh, well, it's got to happen ... Pauline Hanson's first speech in Parliament just a couple of months earlier - warning us that the Asians amongst us will always be alien, and that we are in danger of being swamped by Asians... John Howard our then Prime Minister had defended her 
rights to voice her opinion ... free speech, democracy and all that, only, as it turned out, to be a dog whistle for the one million voters who had flocked to Pauline Hanson from their conservative moorings ...

The 'fact sheet' from the Information Centre continues:

'This positive act in a time of upheaval caused by the intensifying of the immigration and race debate brought the town national and international praise from media and politicians from all sides. The Garden project was covered by the Today Show, John Laws Show, 7.30 Report and the American program CNBC Asia.'

Hmm... I missed all that at the time.

The Mayor formed a Foundation of prominent Australians to assist with further fundraising and the strategic direction of the project. Many prominent members of the Sydney Chinese community were said to have joined the Foundation.

In 1997 Gough Whitlam, Phillip Ruddock, the Ethnic Affairs Commissioner Stepan Kerkyasharian, and a host of politicians launched the Foundation at a dinner in NSW Parliament House, attended by 400 people.

... Ah, the multicultural circus, embedded with a sea of cacophonous Chinese faces herded there by john chinaman compradors - the usual suspects.

'Eventually Council believes that the Lambing Flat Chinese Tribute Garden will become a monument of national significance and one of the New South Wales' major tourist attractions.'

... A nice pat on its own back for the Council, eh! And a bit of tourism promo at the same time. A monument? Not in my book. 
No doubt, the Rotary Club started off with the best of intentions, simple and perhaps even innocently pure. But it has become, like so many initiatives hitched to our multicultural caravan, an exoticised makeover. A genuine copy of the bronze statue, 'Matafeiyan' - 'galloping horse stepping on a flying swallow', excavated in 1969 from an Eastern Han Dynasty tomb, some 1600 years old, stands on the edge of the lake. We are told that this statue 'thoroughly reflects the essence of Chinese culture.'

... Oh, for goodness sake, only a cultural simpleton or a snake oil salesman could say a thing like that!

I can imagine that in some of the many meetings, the project might even have been touted as a 'win- win-win' situation: the public gets a beautified (and exotic) sanctuary; the Chinese, both the early sojourners at Lambing Flat and the latter-day settlers in the cities, get recognition for their contributions; and the Young Shire Council would gain international stature, and receive a shot in its arm - its tourism arm.

And as a nation we could imagine that we have redeemed ourselves in the eyes of the world. We have provided an antidote to Pauline Hanson's spectacularly successful re-launch of the Yellow Peril, just two decades after the surreptitious interment of White Australia.

Yet I can't help feeling that there is a loser - history. The project whited out the dark side of Lambing Flat's early history, and infused it with a latter day gin and tonic, garnished with sinophiliac peelings - the warmed up remains of chinoiserie, a benign aspect of the orientalism of old.

... I can no more let that sleeping dog lie than see a neighbour's house being burnt down, without raising an alarm.

The early Chinese are gone, forever. Most of their descendants have left the district and/or have passed into white Australia a generation or two back. There is no record of how these early Chinese felt about the organized violence inflicted upon them, on that day or during the decades 
thereafter, nor any inkling of what they might have ever considered as appropriate redress, for the memory of themselves or for the destiny of the homeland of their descendants, of one hue or another.

Should we care, 150 years on? There is nothing we can do to make them feel better. Five or six generations on, it is largely a non-issue for their descendants. Surely it's better for all of us to 'move on' ... (and do something positive!) ... To forget, and to forgive tacitly, on their behalf ... I cannot.

The gardens are a sanctuary: the tranquility of the lake, the multitudinous choir of plants native to China, standing at the fringes of the lake and spreading up and down the mounds and alleys which take one to the high point of the sanctuary, the small Chinese pavilion, from where one would see the miniature waterfall from under one's eyes, and follow the mediated torrents prancing their playful ways down the choreographed rocks, only to be expired by the immensity of the vast imperturbable lake.

Above the water and below the clouds, the murmur of the torrents, the smell of the plants, the call of the birds ... there always to set free every fibre in our laboured bodies. Close your eyes, and spirit yourself temporarily into Omar Khayyam’s paradise enow!

Do I have the right to spoil it all for all those well-intentioned people, rotarians, shire elders, champions of multiculturalism, born-again john chinamans, by pointing out their collective failure in keeping faith with history, and in upholding the moral integrity of public monuments?

... Come to think of it, it's a million times better than what they did to the three hundred odd Aboriginal prisoners who were buried in unmarked graves in Rottnest Island, just off the coast of Perth! ... The bus driver, a post-middle age Anglo-Aussie, a self-taught tour guide, informed us in late 2006: a few thousand Aboriginals were brought over here from the mainland until the 1930 s ... for being up to no good ... quite a few died here, diseases mainly ... winters are very cold here, the work would have been pretty strenuous, and Her Majesty's hospitality not the 
best... Now, on the left hand side, at the bend just coming up, was where they were buried. It's now a car park for the mini-golf course.

The Chinese Tribute Garden is a striking example of why we need to move on: it started with the best of intentions through (unenlightened) white eyes; got mediated by the political dictates of the time; and ended up with cameos played by Chinese actors, hand-picked from amongst the present day born-again john chinamans, frolicking excitedly in the multicultural landscape which we have been dreaming about since the 1970s - with much singing and dancing, but with little of lighting up the past in order to light up the present.

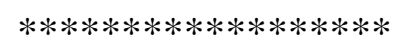

The trials of the early Chinese provide but a platform upon which the born-again john chinaman launches his ascent into the multicultural realms - seduced in part by the ubiquitous multicultural awards, the OAM or the Centenary Medal for contribution to Chinese-Australian affairs (having been, say, the de facto president for life for a Chinese-something organization, or having collected money from latter-day business immigrants for this hospital or that flood), an AM for contribution to international relations, (being the female attaché to a corporate venture in China spearheaded by white Australian males needing a native speaker as the cultural gobetween.) ... The list goes on. And there are seats on this advisory council or that, a useful addition to one's business card when doing business in one's native land in Asia, and well-paid sinecures on boards of government owned corporations where the token chinaman fits in decoratively with the 'equal access' refrain from the government's multicultural song sheets.

Little wonder that there are some 300 Chinese organizations in Sydney today and 200 in Melbourne.

$* * * * * * * * * * * * * * *$

The born-again john chinaman hails from a diverse background, but there is one distinguishing feature about him. Until the advent of multiculturalism he had had little consciousness of or yearning to proclaim his Chinese heritage. But since then it has taken hold of him like an 
addiction. The native born-again john chinaman who hails from amongst the descendants of the early Chinese, is almost certain to have lost, most if not entirely, his Chinese heritage quite some time ago, apart from his facial features if that should happen to be the case, as his forebears had almost without exception deliberately not passed on any aspect of their Chinese heritage - to give him the best start in life, such being the tyranny of White Australia; on the other hand, the immigrant born-again john chinaman, those who have immigrated during the 'multicultural' era since the 1970s, from all over Asia, is one who has suddenly realized the potential of an asset he has inherited - the Chinese-Australian brand, a commodity that can be floated on the multicultural stock exchange to his social, political, and financial advantage.

Doing the 'right' thing, to gain acceptance from the White powers that be, is second nature to the native born-again john chinaman; and as for the immigrant latter-day born-again john chinaman, exploiting his new-found Chinese-Australian brand is not unnatural - trying to find a foot-hold in an unfamiliar and not entirely fathomable social setting can and does compromise one's sense of self.

But why do the powers that be allow this state of affairs to flourish, indeed encourage it to take on the sheen of the golden mean for racial harmony, and to persist in rewarding those chinamans who do the 'right' thing in the choreographed multicultural landscape?

John Chinaman of course has loomed large, time and again, in the mindscape of Australia, since the mid 1800s. He was an object of ridicule, fear, and hatred: in cartoons, in poems and widely propagated ditties, in newspaper articles, and in books, until the battle against him was decisively won at Federation. No more chinaman could come in, no more naturalization for him: he would simply fade away, and Australia would be white.

In all, about 100000 Chinese came by late 1800s. At Federation about 30000 remained, in a population of nearly 4 million. (some 20000 had died and been buried in terra nullius.) And by 1947 just 6400 Chinese were counted in a population of nearly 8 million. The dream of White Australia, a 'new britainia' of sorts, was all but achieved. 
But John Chinaman did not disappear entirely in white Australia’s imagination. In fact in the intervening years, he was being rehabilitated, somewhat. A gentle tic of his imminent passing might have come to pass, perhaps not unlike the pang that drove the smoothing of the pillow for the Aboriginal peoples who were to die out, as nature had predestined and white man had instrumentally helped it along with diseases, starvation, and guns.

In time John Chinaman would appear in Australian fictions as 'Chinese with white hearts', hardworking, honest, reliable, but above all loyal to his white employers (Aitken 2009): just one step away from the emancipated and liberated Chinese-Australian - loyal to the national interest of Australia, without being obsequious or apologetic, without fear or favour.

But the Cold war intervened. Menzies got us all obsessed with the Red Menace, forever, it seemed. Nonetheless the disintegration of the old empires tolled, and the White Australia drawbridge got lowered down finally in the mid 1970s.

$* * * * * * * *$

The rear guard was restive: within a decade Geoffrey Blainey had launched his public campaign against Asian immigration; in 1996 Pauline Hanson, a candidate in an impossible-to-win seat and dis-endorsed by the Liberal Party during the campaign, had burst into Parliament. She had achieved the impossible, by rekindling the fear of being swamped by Asians. John Howard took good notes, and embraced her xenophobic offerings to craft a triumphant victory in the 2001 Tampa elections (Kendall 2005). The Tampa was a god-send. Its load of middle eastern asylum seekers, rescued from a sinking boat, was perfect for a new refrain on being swamped by aliens with incompatible culture and foreign contagions, this time that of terrorism.

Race is still an issue, lurking about 35 years after the planting of our multicultural garden.

And John Marsden's popularity with young Australian readers in his Tomorrow series, sequeled by the trilogy, The Ellie Chronicles, would portend that 'white Australia being invaded by Asians' can still be relied upon as a formula for stirring up the subliminal anxiety in our nation's psyche, even amongst the adolescent: the scenario of a (unacknowledged invading) white 
population, still comparatively small, fearful of being invaded in turn by the teeming Asians across our waters, two centuries on, when the adolescent Ellie, the heroine in Marsden’s Tomorrow series, had transmogrified to become the true daughter of native Australia, thus subliminally whiting out the indigenous people from our present mindscape, as if the cherished destiny of the blacks has come, finally, into effect (Ross 2006).

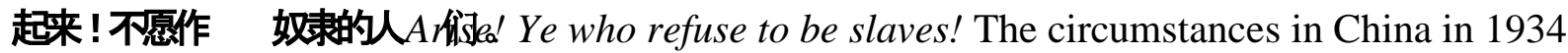
were dire, unimaginable to any of us today, when the poet and playwright Tian Han wrote that opening line to the March of the Volunteers which was to become the Chinese National Anthem, at various times, since. Yet, his call to rise up to become free, in spirit, at least, rings a bell for me, even in today's Australia.

In 1996, in the wake of Pauline Hanson's explosion into our national life, a young, up and coming politician came to the Queensland Chinese Forum and told the assembled Chinese community leaders that we the Chinese could not fight this battle on our own. We needed them, the white Australians, to do it on our behalf. His close associate, a consultant, would come up soon after with a 40 month community based campaign to present a positive image of multicultural Australia, right up to the Sydney Olympics. 'We will show the world!' The Chinese in Queensland just have to put up the money for a Secretariat, the consultant's fees plus his expenses, and the running costs of the entire campaign. Meanwhile the young politician told us that it would be good if the Chinese and Vietnamese could organize weekend trips to Nambour, the heart of Pauline Hanson's support base, to provide free medical, dental, and other services to the people there ...

Jeez, we are all right now ... trusted even to provide professional services ... just accept gratefully the hand of the self-appointed white patron, fund and support his vision of an Australia that the rest of the world should see, and we're gonna be fine. Pauline Hanson would be edited out of our collective mindscape ... and we 'the Asian Australians' would be happy little vegemites prancing about innocently in our multicultural garden of paradise... and furthermore, 
we have even been handed an opportunity to display our noble self ... be extra good fellows towards those who happen to see us as an object for their many-layered grievances ... in the hope that they might then relent and accept us? ... Christ Almighty!

A few years later, in 2001, Cathie May wrote, on behalf of the Chinese, without our knowing, Chinese in Queensland in The Australian People: An Encyclopaedia of the nation, its people, and their origin. She was then living in Western Australia and had retrained as a lawyer. Years earlier I had read her 1984 book, Topsawers: the Chinese in Cairns 1870 to 1920, based on her $\mathrm{PhD}$ thesis. That work seems to have been the main source for her contribution to the Centenary of Federation edition of The Australian People, 20 years later. The last two paragraphs of her 2001 contribution, about $10 \%$ by word count, were devoted to the post White Australia period, during which most of the present day Chinese in Queensland came. There are statistics on when and where we had come from; a sentence on how China has become a place of interest to (white) Australians: and the claim that there is now 'genuine social integration and cultural exchange between Chinese and Europeans ...' at the end of the article.

Ah, the multicultural drum roll ... in the absence of any knowledge of how the present day Chinese are actually faring in trying to find a foothold in today's Queensland. A few words from the mouth of a Chinese surgeon, an accidental settler from the Tiananmen fallout, working as a machine operator for a health supplements manufacturer would have been telling. Or the tale of a Taiwanese business migrant that got taken in by his local (white) distributors in his wholesale business in Brisbane and went back to university and discovered a way to make a common drug more benign in its side-effects, would have been revealing of the life of a recent business migrant. But the Chinese voice was absent, entirely. There was no empathy, no authenticity, compared with contributions from two other (white) immigrant groups I had a quick read of. A hot surge arose in my chest. ... Was any Chinese person asked to write on this topic? Did she not have the intellectual integrity to realize that she was out of her depth? Did she believe like all white Australians of her parents' generation that that is just what is done? And for god's sake, using the word Europeans, instead of Australians, or white Australians, in fact! ... hiding behind some inherited subliminal guilt? Or just being twee? 
It seems that at the centenary of the Chinese being legislated into the status of tolerated aliens who would fade away in due course, we are still a people to be talked about and written about by the Other.

When will the Chinese find their voice?

And just last year, a first time (white) MP prime-moved to have a Chinese War Memorial built in the grounds of the RSL sub-branch in a suburb within his electorate. It is a suburb in which the Queensland Chinese are most highly concentrated. There is already a memorial bell in the Fortitude Valley Chinatown, a purpose built commercial artifice, in memory of the Chinese who took part in the Wars, funded with 'grants' extracted from all levels of governments just a little time before various elections.

The insert in the local Chinese newspaper proclaimed: 'This project is not just about erecting a monument. It's about educating school children and the broader community about the stories of service and sacrifice of Australian Chinese in the armed forces.'

Billy Sing, the Gallipoli sniper, born of a Chinese father and an English mother, was the hero made much of in the launch of the project by the said MP. Further community input was sought, the newspaper insert concluded.

... Ah, glorifying war has surely lost its sheen ... At best war is a necessary evil, as the last resort ... He should move on, and if he is dinkum, he'll accept my suggestion that the Canadian model be adapted for our project ....

At the following meeting it soon became clear that everything had been sewn up. In short order an official launch for the project was decided in the form of a Chinese banquet to which the usual 'Chinese community leaders' can be expected to find the Chinese to fill the tables. A letter is to be sent the very next day by the MP to his colleagues, the relevant Federal Ministers, to see if one or more of them could come to Brisbane to officiate at that gala evening. The meeting was 
all over in an hour, but not before the Chinese community leader held out his hand for funds from the targeted visiting Minister, through the MP of course.

The minutes of the meeting came out shortly after, but they make no record of my suggestion that we could consider the example of the memorial to Chinese Canadians in Vancouver. It honoured not just the soldier but also the railway builder. The memorial was in front of the Chinese Cultural Centre which amongst other things houses the Chinese Canadian War Museum. The scale is of course far too big for us, but the concept might be apt. We could for instance have a memorial to the early Chinese as a whole. They were dominant in the commercialization of the banana industry in North Queensland for a few decades after the 1880s; the Chinese market gardeners at Breakfast Creek supplied almost exclusively all the fresh produce for Brisbane by 1888; and there was also Charles Lee, a Queenslander who was sent to our embassy in Chungking during the War. And if we build the memorial in the ever expanding restaurant, shopping, and business centre, clustered around an intersection in the electorate, it would serve its stated purpose of educating the broader community so much better, and on a daily basis. Besides, the subject matter then would be much more amenable to the telling of the history about the early Chinese, in schools and on the internet. By contrast Billy Sing went downhill soon after he got back from the war, died alone in his room in a Brisbane boarding house in 1943 at 57, and never had a family. His Scottish wife, whom he married during a four week leave whilst stationed in England, never arrived in Australia, despite instructions to our man in London to have her 'repatriated' expeditiously, after the War. There was 5 shillings in his pocket, and not much else of worth. ... He was in all probability the knockabout Aussie that needed a war to become a hero, nothing much before, nothing memorable after. Yet somehow he is now to be the archetype for the 'model Chinese Australian'?

The Chinese in the steering committee were largely from one group ardently supportive of the idea. As is culturally pre-determined few of the less-than-a-handful of the other Chinese also there, could be expected 'not to do the wrong thing' - by questioning the rationale of the whole idea, when it was just about all sewn up and dusted. What is there to gain from such a fool-hardy move? Better to bide one's own time, eh! And there was no-one from the Taiwanese, the PRC, 
and the Malaysian Chinese organizations, the numerically dominant Chinese groups in that electorate.

It's a marginal electorate, where the 'Chinese vote' if channeled would no doubt be pivotal.

Has John Chinaman metamorphosed into a modern day comprador, (the middleman who did all the dirty work for his white master, sovereign within the 'concessions' in the port cities of China, after the British invasion of China to assert its right to sell opium in China), always ready to receive favours from the powers that be in return for delivering the political commodity, Chinese-Australians, selectively packaged for each occasion? A sort of 'Chinese with white hearts', depicted in the Australian fiction of the $20^{\text {th }}$ century, but with an implant secreted under the blanket of multiculturalism that conferred upon him a 'respected voice' which the powers that be appropriate and make consonant with their own political ends from time to time? Yes, in the past they simply told the Chinese how unworthy and objectionable they were. 'It's progress', some of you might say.

Be that as it may, the white powers that be continue to speak on behalf of the Chinese, often with the Chinese playing bit parts, or merely providing the raw material in the construction of what I call the mediated Chinese Australian Perspective. Some think it is just how it is. Others can't help themselves and are part of the gig. Good intentions are not always absent. It is just that it has become a bit of an industry. The Chinese, their history, their heritage have become a commodity transacted in guises as varied as academic research, tourism and political votebuying.

However John Chinaman is no longer the object of ridicule, fear or hatred. He has had a makeover, with the best of aussie cosmetic surgery: respect, exoticness, and a 'rich cultural heritage’ bestowed upon him in public ceremonies staged at appointed times, featuring him as a leading dancer in our multicultural song and dance troupes.

The born-again john chinaman ventriloquises for the white powers that be, avowing that the Chinese are happy, exotic and enterprising people, energetically toiling away in our wonderfully 
multicultural garden. There is no past; only the present, verdant and vivacious. He has moved on, he says, over and over.

It reminds me of Barack Obama’s predicament when his white mother, visiting him in Chicago, took him to see the 1950s film, Black Orpheus, based on the tale of the feckless lovers, Orpheus and Eurydice, shot in Rio during Carnival. He wanted to leave at intermission, not liking the way the blacks were portrayed as childlike people prancing about in their colourful attire. But when he turned to face his mother he faltered. She was still wistfully entranced by the film, 30 years after she first saw it at 16.

Short of a properly constituted institute for Chinese-Australian affairs, I cannot see how the Chinese will ever have a public voice in Australia. The latter-day Chinese have come from all over Asia, with their disparate social, cultural, and political backgrounds: from Mao’s red guards who somehow made it through China's top universities, to heirs of well-to-do Chinese middlemen in ex-British colonies who know not a single word of Chinese, to refugees who have no exposure at all to anything British. Apart from Chinese food, there seems to be little that coheres: there is no common spirit for the present; nor anything of a vision for the homeland of their heirs. For a people still being visited upon periodically by hostile social attitudes, first incubated in the 1850s, it beggars belief that we are so deaf to the voices of history and so heedless to the calls for a nobler society.

It would help of course if academics, researchers and 'consultants' were to get their hands dirty and immerse themselves in Chinese organizations and their current comings and goings before they assume the de facto role of speaking on behalf of the Chinese in Australia. But they would need to learn to fathom the cultural dynamics sufficiently to realize when they are being told things which their Chinese informants think they ought or want to be told. In this regard many 'oral history’ or 'heritage’ projects about the Chinese have been undertaken by people, many well-meaning, with little to indicate that they have the requisite cultural empathy with their subjects. The result is often a 1950s chop suey, liberally sugared and oiled to appeal to the uninitiated when it should have been liang gua, a finely crafted bitter gourd dish to inspire the 
discerning. Such outcomes serve but to prolong the shelf-life of john chinaman in the minds of the remaining rearguards of White Australia.

$* * * * * * * * * * * *$

Earlier last year I went to see Mao's Last Dancer. It was a clever adaptation of his memoirs. A few days later, over breakfast, I read that this aussie-made film had grossed $\$ 12 \mathrm{~m}$ in five weeks, and was No.2 on the Top Ten Critical List.

Li Cunxin, the film's hero, had already achieved something of a cult status before the film was made. His memoirs had made him a literary figure, and a sought after motivational speaker. He has achieved the honorary white status: exotic; with the celebrity status that Aussies by and large are conditioned unconsciously to adore. Just before the credits, we are told that he and his (white Australian) wife, Mary, and their three children now live in Melbourne. What a lovely ending. ... and what a wonderful world we live in now.

The fairy tale might have ended after we left the cinema, but subconsciously we may feel that we have finally moved on in Australia. Race is not an issue any more, and perhaps ChineseAustralians could even play a part in the warming up of bilateral relations with China - that benign panda in the economic scenarios of Australia 2020 and beyond.

Li Cunxin may well be remembered one day as the Quong Tart of the 21st century - a latter-day Chinese-Australian whose personal status transcends the unflattering images that had plagued the john chinaman who came before him but did not make it to the honorary white echelon.

He is not the only one who has made it though. There is, for instance, Victor Chang, the immigrant Chinese, our acclaimed heart surgeon; or Penny Wong, our world striding cabinet minister, who came here at eight, portrayed unmistakably in the media as Chinese or Asian, despite bearing at 50\% the Irish genes of her Australian-born mother; or Cathy Freeman, our black Olympic Gold Medalist, native born and bred for eons, whose Chinese ancestry somehow remains unremarkable, uncelebrated. 
And for every Cathy Freeman there are hundreds if not thousands of Edwina Chens and Anton Tangs who feel no particular need to celebrate their Chinese ancestry. They have all the advantage of being born of Chinese parents ushered into Australia as skilled or business migrants in the last two decades. They reap the best of what money and privilege can and do afford them in the $21^{\text {st }}$ century Australia where the Chinese do not have to apologise for their presence, anymore.

In fact, the majority of Chinese Australians today go about making a life for themselves without coming face to face with arbitrary hindrances placed before them in any overwhelmingly pervasive way.

Just now and again something erupts, like an old scar. The online comments to the articles in The Australian on the 'whiting' of Billy Sing in a mini television series some months ago is an example. On that occasion the remains of White Australia shimmered. The epithets have metamorphosed though: the Chinese should not complain... Billy was Australian ... using a white actor in his role is no big deal ... Even so a concession has been allowed. The Chinese are part and parcel of Australia now, provided that they do not complain about being improperly treated, as if they should know their place in Australian society. I wonder what John Marsden’s Ellie, the made-to-be true daughter of Australia, would say about this little episode.

On the whole the Chinese are all right now, unlike the hapless latter day Muslims. Nevertheless, the Lambing Flat Chinese Tribute Gardens, the mediated Chinese voice through (untutored) white mindsets in this historical publication or that academic discourse, the commodification of the chinese-australian identity in the multicultural stock exchange, the exoticisation of all things Chinese in our tourism, cultural, and academic undertakings, the hand-feeding of the born-again john chinamans to become dummies for the ventriloquist white powers that be, all furnish reasons enough for me to want us all to Move on, Move on, ON! 


\section{Bibliography}

Aitken, A. 2009, "Ouyang Yu - Chinese in Australian Fiction (1888-1988)."

http://adamaitken.blogspot.com/2009/06/ouyang-yu-chinese-in-australian-fiction.html May 30, June 18 and June 252009

Kendall, T. 2005, 'Using the Past to serve the Present: Renewing Australia's Invasion Anxiety', East by South: China in the Australasian Imagination, in Miller, P., Smith, K. \& Ferrall, C. (Eds)Wellington, Victoria University Press, pp128-129.

Ross, C. 2006, 'Prolonged Symptoms of Cultural Anxiety: The Persistence of Narratives of Asian Invasion within Multicultural Australia'. A. D. Hope Prize 2006. Association for the Study of Australian Literature, vol. 5 2006, p94. 